\title{
Pedagogic technology of formation of readiness for self- development in students from the occupied territories and delimitation line in the east of Ukraine in conditions of temporarily displaced higher education institutions
}

\author{
Vitalii Kurylo ${ }^{\mathrm{a}}$, Iryna Trubavina ${ }^{\mathrm{b}}$, Olena Karaman ${ }^{\mathrm{a}}$, \\ Viktoriia Stepanenko ${ }^{\text {a }}$, Yaroslava Yurkiv ${ }^{\text {a }}$ \\ ${ }^{a}$ Luhansk Taras Shevchenko National University, 1 pl. Gogolia, Starobilsk 92703, Ukraine \\ ${ }^{b}$ National Academy of the National Guard of Ukraine, 3 maidan Zakhisnykiv Ukrainy, Kharkiv 61001, Ukraine
}

\begin{abstract}
The topicality of the research is connected with the need to develop a technology of preparing students for learning for life, developing their professional self-development at a temporarily displaced higher education institution in conditions when students' primary and basic needs are insufficiently satisfied. The methods of the research included analysis, synthesis, comparing, systemizing, interviewing, pedagogic experiment, modelling, prognostication, mathematic statistics methods. The level of the analyzed phenomenon turned out much lower than that in students from the safety zone by the following parameters: self-management, gnostic, motivation, moral-and-will, and communicative components of readiness, conditions, mechanisms, and general level of self-development. The scientific novelty: the efficiency of such a technology was proved and justified, and its content was revealed.
\end{abstract}

Keywords: readiness for self-development; pedagogical technology; students of higher educational institutions; temporarily displaced universitie

\section{Introduction}

The current social development is characterized by rapid changes, a rapid renovation of technologies and various spheres of human activity, a raise in education quality in the context of European integration, and a raise in specialists' economic and geographic mobility. This brings up the issue of their competitiveness, permanent professional development, and readiness for self-development as interrelated processes (Frytsiuk \& Groshovenko, 2018), which leads to the need in designing and testing pedagogic technologies aimed at forming readiness for self-development in higher education institutions' (HEI) students as specialists-to-be, where readiness for self-development acts as an element of competitiveness and permanent professional development. Such technologies should be implemented on several levels: the individual one (where an impact is made on an individual); the local one (which presupposes the need in forming conditions for implementing corresponding technologies at a HEI); the national one (which ensures competitiveness of the state and support of its high standards owing to implementing such technologies at HEIs); the international one (which ensures competitiveness of specialists and the country in

* Corresponding author. Tel.: +38-066-764-1783; fax: +38-097-567-2045

E-mail address: yurkiv.yara95@gmail.com

DOI: $10.51865 / J E S P .2021 .2 .06$ 
general in international cooperation, and people's mobility). It should also be noted that higher education and professional training indicators act as signal criteria in determining the global competitiveness index (GCI) of a country (Liulyov et al., 2018; Zubchyk, 2014). Therefore, this highlights the prospects for organizing HEIs' work on development of technologies to form readiness for self-development in specialists-tobe within the context of strengthening their competitiveness, raising the general rating of the country by these indices, and possibilities for the international cooperation. On the other hand, these technologies correspond to the ideas of education quality which are part of sustainable development goals, and andragogic ideas of education for life (Trubavina \& Kaplun, 2019). It is at a HEI where proper education for life begins due to the formation of readiness for self-education, general competencies, while permanent self-education should be based on students' readiness for self-development in their aspiring for the acme-top level (Rybalko, 2017).

Currently, Ukraine has taken the course for integration into the European education environment, which presupposes independence and the subject status of the participants of the training process, their academic freedom and choice, reformation of the national education system in the context of European standards, development of professional standards for higher education, orientation at forming conditions for training competitive human capital for highly-technological and innovative development of the country, personality self-realization, ensuring the needs of society, labor market, and the state in qualified specialists, a raise in citizens' education level (The Law, 2017; The Law, 2014). Nevertheless, a prolonged military conflict in the east of Ukraine has complicated for HEIs, especially the displaced ones, attaining of this goal, and has put to the Ukrainian state and HEIs acute questions concerning the rights of children and youths from the occupied territories and the delimitation line. Among such rights is granting to young people wishing to study in Ukraine the possibilities of obtaining a higher education. As a rule, they apply to the displaced HEIs that resumed their work in towns controlled by the Ukrainian government, and experience problems connected with the organization of the training process without the necessary up-to-date material conditions, satisfaction of the needs of the main education process participants, the absence of hostels for both students and teachers, the problems connected with the status of internally displaced persons (IDPs), their psychological state, social well-being, adaptation, communication, self-control, etc. (Chaltseva, 2019; Kurylo \& Savchenko, 2019; Trubavina, 2015).

Therefore, the basic needs of students and teachers have not been satisfied, although the needs of a higher level are being satisfied: safety, social needs (the needs of belonging to Ukrainian society, to students community), the needs in recognition (the need in respect and competency), which raises a question on a possibility of forming on this basis the highest level needs: the needs in self-expression (the need in personal self-perfection, the need in personal development). There arises a question, how without satisfying the basic needs is it possible to form in students' readiness for self-development at a displaced HEI? Besides, the process of the formation of readiness for self-development presupposes solving a number of tasks both in the near perspective (optimizing a student's life - training, public, personal life), and in the middle perspective (obtaining an efficient, quality education), and in the distant perspective (realization of one's professional potential with utmost efficiency and good for both the society and the personality) (Zelenov, 2015). This is a complicated task, for according to the authors' observations, the furthest time-period the IDPs aged 23 to 60 vision themselves on the life scale is from a fortnight to a month. Moreover, even among pedagogues and experienced psychologists from the interviewed group (22 people), only one person sees herself on the life scale 5 years into the future; this is a graduate student at Berdyansk Pedagogic University. The rest demonstrated the same time-period as the IDPs. The exercise on positioning oneself on life scale was conducted by the authors during implementing the $\$ 1.5$ million European Council project in the town of Berdyansk concerning the support of IDPs and the town community in 2017 (Trubavina et al., 2017). That is to say, that even adults with employment and accommodation find it difficult to determine their goals and their future in ever changing Ukrainian realities, let alone IDP students in a new social and 
education environment, new conditions of life, without satisfying their basic needs. This requires from a HEI to rethink its own role and mission in the relocation conditions for the sake of preserving education quality, forming competitive specialists ready for self-development in the changeable conditions, and devising of a technology for developing such readiness (Kurylo et al., 2019). Consequently, raising higher education quality within the euro-integration context presupposes the need in a student's cognitive independence that enables a person to set goals freely, and find independently the most efficient ways of attaining them. This means the need in highlighting the subject status of a student in the course of training. It is proved that forming subjectivity through learning and cognitive activities enhances cognitive independence formation (Trubavina \& Kaplun, 2019).

Subjective perception by students of the content and the process of readiness for self-development predetermines the existence of a group of pedagogic technologies with correspondent orientation that direct the organization of this readiness at activating in a personality the "selfness" processes with subsequent forming the Iconcept of professional self-development by way of guiding a student from present-I (the real) to future-I (the ideal) (Tsyna, 2019). Therefore, an individual trajectory for a student's development within this technology should be provided for in conditions of a displaced HEI. On the other hand, students are not objects of education anymore, but its full-fledged subjects and participants, which is stated in the new legislation on higher education. At the same time, student-centrism alone does not ensure formation of readiness for self-development in students.

At present, there are numerous papers concerning various aspects of a personality self-development, self-identification and factors that facilitate or impede these processes. (C. Day, A. Kington, G. Stobart, P. Sammons (Day et al., 2006), T. van Lankveld, J. Schoonenboom, M. Volman, G. Croiset, J. Beishuizen (Lankveld et al., 2017), J. Hong, B. Greene, J. Lowery (Hong, 2017), C. Rodgers, K. Scott (Rodgers \& Scott, 2008), A. Urzua, C. Vasquez (Urzua \& Vasquez, 2008), etc.). Conceptual foundations of professional self-development in students are found in national and foreign studies by O. Ignatyuk (Ignatyuk, 2009), A. Smolyuk (Smolyuk, 2017), G. Kelchtermans (Kelchtermans, 2009), B. Yazan (Yazan, 2018), D. Hamman (Hamman et al., 2010), etc. The peculiarities of self-education in the process of teachers' qualification improvement, the role of self-reflection in personality development of a teacher as related to his/her social actions were studied by K. Pithouse, C. Mitchell, S. Weber (Pithouse et al., 2009), A. Nevgi, E.Löfström (Nevgi \& Löfström, 2015), E. Gheith, N. Aljaberi (Gheith \& Aljaberi, 2018), etc. Currently, the problems of students' readiness for self-educating activities in the context of higher education, a personality's socio-psychological characteristics and organizing-and-pedagogic conditions that may serve a foundation for their readiness for self-development are actively being studied (V. Kravchenko (Kravchenko, 2016), S. Kuzikova (Kuzikova, 2020), I. Martyniuk (Martyniuk, 2019), V. Frytsiuk (Frytsiuk, 2016), I. Kucheryavenko (Kucheryavenko, 2011), N. Myronchuk (Myronchuk, 2013), A. Polyakov (Polyakov, 2008), etc.).

The peculiarities of working at displaced HEIs found their reflection mostly in works by scholars of those HEIs (Chaltseva, 2019; Kurylo \& Savchenko, 2019; Kurylo et al., 2019; Kasyanova \& Kolosov, 2018; Kurylo et al., 2020). These peculiarities are related to the history of their relocation, preserving the pedagogic and students' collectives, analysis and formation of material-technical basis of HEIs, their operation in a new place, specificity of HEIs' relations with local authorities, and so on. Nevertheless, the results of the mentioned researches do not give an answer to the question on a specific technology of formation of readiness for self-development of students at displaced HEIs, although they do provide materials for developing it. In scientific literary sources there are scientific studies dealing with the structural models and technological principles for teachers' self-development, which are presented in works by V. Alpatova (Alpatova, 2012), M. Ahmetov (Akhmetov, 2004), K. Babak (Babak, 2011), V. Blinova, Yu. Blinova (Blinova \& Blinova, 2009), S. Kuzikova (Kuzikova, 2020), S. Minyurova (Minyurova, 2013), L. Rybalko (Rybalko et al., 2013), etc. Nevertheless, despite a sufficiently wide spectrum of researches dedicated to the 
issues of self-development and readiness for it in specialists-to-be and education staff, the authors are positive that the technology of formation of readiness for selfdevelopment in students from the occupied territories and the delimitation line in conditions of a displaced HEI without satisfying their basic needs has not been theoretically developed; there are no empiric studies as to peculiarities in implementing it in the described conditions.

In their previous publications, the authors disclosed the basic problems of IDPs and their children (Trubavina, 2015; Trubavina, 2018), problem aspects and perspectives of development of the displaced HEIs (Kurylo et al., 2019), development of Soft Skills and communicative competency as general and professional competency in specialists-to-be. Consequently, these competencies ensure successful professional activity, high efficiency, and self-development for a specialist in the described conditions (Kurylo et al., 2020). In the mentioned work, the factors were also detected that influence the formation of communicative competency and general competency in teachers-to-be, in particular students' attitude to self-development, self-education, students' life and social experiences, motivation to obtain a profession, humanistic orientation of a future teacher's personality, etc. (Trubavina et al., 2020). In addition, subject status and forming of HEI students' independence were considered as interrelated conditions of their formation as specialists-to-be (Trubavina \& Kaplun, 2019). Nevertheless, all these researches only partially disclose individual aspects in forming readiness for self-development in students from the occupied territories and the delimitation line in the east of Ukraine, without describing the technology as a whole. This technology has to be pedagogical, for it concerns higher needs of a personality - the education process, where students spend most of their time, and this time should be deliberately planned by pedagogues in order to form competencies and readiness for self-development, which is a program outcome of training by many standards of specialists training in many branches.

The goal of this research is a theoretic substantiation, introduction, and experimental verification of the pedagogic technology of the formation of readiness for self-development in students from the occupied territories and the delimitation line in the east of Ukraine in conditions of a displaced HEI and unsatisfied basic needs of students and teachers in the context of permanent professional and competitiveness development. The tasks of the research are as follows: 1) to determine the parameters and the initial state of readiness in students from the occupied territories and the delimitation line in the east of Ukraine for self-development in conditions of a displaced HEI; 2) to substantiate theoretically and to introduce such a pedagogic technology of the formation of readiness for self-development in students from the occupied territories and the delimitation line in the east of Ukraine in conditions of a displaced HEI; 3) to verify experimentally its efficiency in conditions of the displaced HEI Luhansk Taras Shevchenko National University.

\section{Methodology}

\subsection{Objective}

The theoretic substantiation of the technology of the formation of readiness for selfdevelopment in students from the occupied territories and the delimitation line in the east of Ukraine in conditions of a displaced HEI was made by the authors with taking into consideration the following technological criteria: conceptuality, systemacy, controllability, reproducibility, efficiency. To this effect, the determination of the conceptual provisions of the theory reflects the methodological foundation of the pedagogic technology, enables implementing scientific approaches and the logic of constructing the research-and-experimental work. In their interpretation of the concept of "pedagogic technology", the authors note that in science literature sources, this notion is used in various aspects, in particular: as a certain system; as a direction; as a sum total of scientifically justified methods of psychological influence on a person or a group; as a sum total of actions, operations and procedures that ensure obtaining an 
expected result in conditions of ever changing education process; as means and mechanisms of activity, organic combination of which ensures success; as a sum total of attitudes that ensure selection of forms, methods, means, activity modes, which are oriented at needs satisfaction of both a personality and the country. That is why, the authors have selected the definition by the UNESCO, where a pedagogic theory in its general meaning is understood as a system method of forming, applying, and determining the whole education process and knowledge acquisition with taking into account technical and human resources and their interaction aimed at optimizing education.

\subsection{Participants}

The research was conducted on the basis of Luhansk Taras Shevchenko National University within the EU project "Intensification of Luhansk area teachers' influence on the processes of reconciliation and establishing peace", one of its tasks lay in providing education and psychological services, development and implementation of students education programs aimed at development of skills in personality and professional growth. 204 students from Luhansk Taras Shevchenko National University of the $4^{\text {th }}$ year of studying (Bachelor's degree) took part in the experiment. Of them, 101 students were the students from the occupied territories and the delimitation line in the east of Ukraine, and 103 students were from the safety zone.

\subsection{Instrument}

Departing from the aforementioned studies, the theoretic-and-methodological basis of this research is a complex of scientific approaches, which will be enumerated in the substantiation of the technology section. Also, the authors have taken into account the didactics principle of educative training, according to which a teacher through carefully selected content of training, the methods and forms applied by them, and his own example, shapes readiness for self-development in students. The authors also relied on the principle of stimulating for self-education, which supposes tutors' work with students at all stages of education. This means that the technology of the formation of readiness for self-development includes both education and training process, therefore the technology is wholesomely pedagogical, not purely didactic or educative.

In their research, the authors based on understanding self-development as a system phenomenon of a personality's self-changing, which takes the central place in their personal and professional growth and ensures a steady motion and positive dynamics of discovering their inner strengths that enhance development of their skills. A personality's readiness for self-development is considered by authors as an intricate integral personality construct, a complex of individual-and-psychological personality traits, which represent a potential in their attaining success and self-realization in professional activity, ensure competitiveness of a specialist in the labor market, understanding requirements put forth by the society, correlation of their needs, abilities, claims level with the efforts needed for attaining a certain result. The components of this readiness are organization (including self-management, conditions, mechanisms), gnostic, cognitive, motivation (first of all, needs), moraland-will, and communicative constituents of personality development. Also, in their research, the authors have taken into account various needs of a displaced HEI students: material, economic, socio-pedagogic, psychological, legal, medical, social, peculiarities of the work of displaced HEIs, current developments of students training technologies, the need in ensuring an individual trajectory in educating a student. This means the need in relying on a number of scientific approaches to development of such a technology in the course of research.

For attaining the goal and solving the set tasks, the following methods were applied in the course of the research: analysis, synthesis, comparing, systemizing, abstracting, interviewing, pedagogic experiment, modelling, prognostication, mathematic statistics. The diagnostics instruments included the questionnaires: 1) "Diagnostics of 
partiality readiness for profession-and-pedagogic self-development" enables defining the respondent's skills and abilities level by the following self-development components: motivation, cognitive, moral-and-will, gnostic, organizing, selfmanagement, communicative; 2) "Dispositional characteristic of a personality's selfdevelopment - DCPSD" (by S. Kuzikova) aimed at studying the actuation level of psychological resources of a personality's self-development by the following scales: needs in self-development, conditions of self-development, and self-development mechanisms (Kuzikova, 2020). The choice of the mentioned methodologies is predetermined by their optimality, universality, and integrity, which enables obtaining complete information in quite a wide spectrum of parameters characterizing students' readiness for self-development at the same time.

\subsection{Procedure}

The pedagogic technology of the formation readiness for self-development in students from the occupied territories and the delimitation line in the east of Ukraine contains the following aspects: 1) the scientific one - the development of the goal, content, forms and methods of work, designing the process of the formation of readiness for self-development; 2) the procedural-descriptive one - an action algorithm in the process of implementing the technology of the formation of readiness for self-development in students from the occupied territories and the delimitation line in the east of Ukraine, which ensures attaining of the expected results; 3) the procedural-acting one - the implementation of the technological process, ensuring operation, interaction, and interconnection of all the components of the developed technology, understanding of personality and professional self-changes of the internal and external processes.

\subsection{Data analysis}

Data processing was made with Statistica 12 program. The research-andexperimental work was undertaken with the observation of ethical principles of organizing and conducting experiments with people.

\section{Results}

The analysis of the science literature sources concerning students' readiness for self-development made it possible to establish its parameters, which became the main criteria for diagnostics at the initial stage of the experiment: needs, conditions, mechanisms, self-management, gnostic, organizational, cognitive, motivational, moral-and-will, and communicative components of a personality's self-development. By these parameters, in September 2019 (at the beginning of the academic year), the state of readiness for self-development in students from the safety zone (group I) and the occupied territories and the delimitation line in the east of Ukraine (group II) was determined in the course of initial diagnostics. The verification of all distributions in the indicators of students' readiness for self-development in the studied groups by means of Shapiro-Wilk and Kolmogorov-Smirnov criteria attested that they do not obey the Gauss law, which determined the use of non-parametric methods of mathematic statistics. By means of Mann-Whitney's U-criterion, it was established that group I and group II did not differ from one another by parameters on need in self-development, particularly its cognitive and organizational components. Nevertheless, considerable difference was observed in all other parameters' indicators: conditions, mechanisms, self-management, gnostic, motivational, moraland-will, communicative components, the general self-development level (see table 1). Here, the median (Me) with taking into account the first $(25 \%)$ and the third $(75 \%)$ quarters $(\mathrm{Q} 1-\mathrm{Q} 3)$ indicators of readiness for self-development in group I students was: conditions for self-development $\mathrm{Me}=37$ (33-41) self-development mechanisms $\mathrm{Me}=37$ (34-40), self-management $\mathrm{Me}=34$ (26-38), gnostic component of self- 
development $\mathrm{Me}=78$ (65-95), motivation $\mathrm{Me}=41$ (32-47), moral-and-will $\mathrm{Me}=43$ (31-49), communicative $\mathrm{Me}=27$ (23-35), general self-development indicator $\mathrm{Me}=108$ (98-114). In its turn, in group II the indicators were as follows: self-development conditions $\mathrm{Me}=35$ (27-38), self-development mechanisms $\mathrm{Me}=36$ (32-38), selfmanagement $\mathrm{Me}=30$ (24-37), gnostic component $\mathrm{Me}=74$ (58-82), motivation $\mathrm{Me}=38$ (30-43), moral-and-will $\mathrm{Me}=37$ (28-47), communicative $\mathrm{Me}=26$ (21-32), general self-development indicator $\mathrm{Me}=101(93-111)$.

Table 1. Outcomes of initial diagnostics of comparison of readiness for self-development indicators in students of group I and group II

\begin{tabular}{llllllll}
\hline $\begin{array}{l}\text { Self-development } \\
\text { indicator }\end{array}$ & $\begin{array}{l}\text { Rank } \\
\text { Sum } \\
\text { group I }\end{array}$ & $\begin{array}{l}\text { Rank Sum } \\
\text { group II }\end{array}$ & U & Z & p-value & $\begin{array}{l}\text { Z } \\
\text { adjusted }\end{array}$ & $\begin{array}{l}\text { p- } \\
\text { value }\end{array}$ \\
\hline General & 11569.5 & 9340.5 & 4189.5 & 2.4 & 0.016 & 2.4 & 0.016 \\
Need & 10873 & 10037 & 4886 & 0.75 & 0.45 & 0.75 & 0.45 \\
Conditions & 11588 & 9321.5 & 4170.5 & 2.44 & 0.015 & 2.45 & 0.014 \\
Mechanisms & 11467 & 9443 & 4292 & 2.16 & 0.03 & 2.16 & 0.03 \\
Motivational & 11469 & 9441 & 4290 & 2.16 & 0.03 & 2.16 & 0.03 \\
Cognitive & 10456.5 & 10453.5 & 5100.5 & -0.24 & 0.81 & -0.24 & 0.81 \\
Gnostic & 11560 & 9350 & 4199 & 2.38 & 0.017 & 2.38 & 0.017 \\
Moral-and-will & 11570 & 9340 & 4189 & 2.4 & 0.016 & 2.4 & 0.016 \\
Organizational & 10728 & 10182 & 5031 & 0.4 & 0.69 & 0.4 & 0.69 \\
Self-management & 11411 & 9499 & 4348 & 2.02 & 0.04 & 2.03 & 0.04 \\
Communicative & 11421 & 9489 & 4338 & 2.05 & 0.04 & 2.05 & 0.04 \\
\hline
\end{tabular}

The data obtained for students' group I coincide with the results of the research by S. Kuzikova (Kuzikova, 2015) (the need, conditions, and self-development mechanisms), O. Sarkisova (Sarkisova, 2015), A. Smolyuk (Smolyuk, 2017) (selfmanagement, and communicative components of students' self-development), N. Chorna (Chorna, 2016) (cognitive, gnostic, organizational, motivational, moraland-will self-development components). This attests to the fact that the general work of the university concerning the formation of the readiness for self-development as of 2019 with students who reside in the safety zone, despite the university operating in relocation conditions, is conducted at the same level as that of the universities that do not experience such difficulties. This also proves the conclusion made by the authors in their previous publication that during the previous six years (2014-2019) many displaced HEIs were able to restore their personnel potential, strengthen material basis, and ensure quality training of specialists (Kurylo et al, 2019).

As to the students of group II, the corresponding studies with students from the occupied territories and the delimitation line were not made, but, as the results of the authors' research demonstrated, their readiness for self-development level was much lower than that of group I. The data obtained at the initial stage of the experiment concerning the readiness for self-development in students from the occupied territories and the delimitation line in the east of Ukraine can be interpreted in the following way. As to conditions and self-development mechanisms, it should be noted that the group in question have demonstrated to a lesser extent the well-developed active life strategies associated with searching activity and self-improvement, autonomy, aspiring for authenticity, positive self-perception, indetermination in goals. The gnostic parameter indicators demonstrated that in students from the occupied territories and the delimitation line the ability for analysis and synthesis, justifying their thoughts, and creativity had also been formed to a lesser extent. In the moraland-will aspect, they possess, compared to the students from the safety zone, a little less developed traits like criticism, independence, workability, finishing a started matter. As to such a self-development component as self-management, it should be stressed that the ability for self-analysis, self-control, and reflection at the initial stage was less characteristic of them. By the motivational component, they possess realization of their own attitude to the chosen profession, understanding their own 
traits and abilities (self-cognizance) that had been formed to a lesser extent. Lower indicators by the communicative component of self-development attested to an insufficient, compared with the students from the safety zone, ability for group interaction and cooperation, work in a team. These results stipulated the need in developing a separate pedagogic technology of forming readiness for selfdevelopment in students from the occupied territories and the delimitation line under conditions of a displaced HEI.

The technology of the formation of readiness for self-development in students from the occupied territories and the delimitation line was implemented within formal and informal education of the 4-year students on the basis of the displaced HEI Luhansk Taras Shevchenko National University in 2019-2020 academic year. The verification of the efficiency of the technology of the formation of readiness for self-development in students' readiness for self-development was conducted at the final stage of the research-and-experimental work and presupposed organizing the final diagnostics in the course of which interviewing of students was held by diagnostic methodologies used at the initial stage of the experiment followed by comparing them with the initial interviewing results. The final interviewing was held in April - May 2020, that is, at the end of the academic year. The median with taking into account of the first $(25 \%)$ and the third $(75 \%)$ quarters of the indicators of readiness for self-development in students of group II on the results of the final diagnostics comprised: selfdevelopment conditions $\mathrm{Me}=35$ (34-40), self-development mechanisms $\mathrm{Me}=36$ (3441), self-management $\mathrm{Me}=32$ (26-37), gnostic component $\mathrm{Me}=74$ (69-88), motivation $\mathrm{Me}=38$ (35-44), moral-and-will $\mathrm{Me}=39$ (35-45), communicative $\mathrm{Me}=31$ (24-32). There occurred a growth in self-development general indicator $\mathrm{Me}=109$ (101-114). The validity of the raise in students' readiness for self-development indicator in group II by all the studied parameters is proved by comparing the results of the initial and the final diagnostics by means of Wilcoxon's T-criterion (see table 2 ). At the same time, the corresponding indicators in group I have also increased (see table 3).

Table 2. Statistical data of comparison of readiness for self-development in students of group II by the results of the initial and concluding diagnostics

\begin{tabular}{llll}
\hline $\begin{array}{l}\text { Self-development } \\
\text { indicator }\end{array}$ & $\mathrm{T}$ & $\mathrm{Z}$ & $\mathrm{p}$-value \\
\hline General & 1118.5 & 4.63 & $<0.001$ \\
Conditions & 1789 & 2.53 & 0.01 \\
Mechanisms & 1655.5 & 2.18 & $<0.03$ \\
Motivational & 1720 & 2.5 & 0.01 \\
Gnostic & 1783 & 2.55 & 0.01 \\
Moral-and-will & 1835.5 & 2.09 & $<0.04$ \\
Self-management & 1717.5 & 2.09 & $<0.04$ \\
Communicative & 1562.5 & 2.53 & 0.01 \\
\hline
\end{tabular}

Table 3. Statistical data of comparison of readiness for self-development indicators in students of group I by the results of the initial and the final diagnostics

\begin{tabular}{llll}
\hline $\begin{array}{l}\text { Self-development } \\
\text { indicator }\end{array}$ & $\mathrm{T}$ & $\mathrm{Z}$ & $\mathrm{p}$-value \\
\hline General & 843 & 5.33 & $<0.001$ \\
Conditions & 969.5 & 2.25 & 0.02 \\
Mechanisms & 776 & 2.1 & $<0.04$ \\
Motivational & 717 & 1.99 & $<0.05$ \\
Gnostic & 1111.5 & 2.44 & 0.01 \\
Moral-and-will & 1061.5 & 2.08 & $<0.04$ \\
Self-management & 1262.5 & 2.03 & 0.04 \\
Communicative & 1266 & 2.01 & 0.04 \\
\hline
\end{tabular}


The obtained results are quite logical because, apart from the application of the authors' technology in group II, the university's general work related to readiness for self-development was being conducted with the students of both groups. This was correspondently reflected by the growing self-development indicators in group I as well. Notably, the implementation of the authors' technology has ensured the attaining by students from the occupied territories and the delimitation line the readiness for self-development level which corresponds to that in students from safety zone, to which effect attests the absence of difference in self-development indicators when comparing both groups at the final diagnostics by means of Mann-Whitney's Ucriterion (see table 4).

Table 4. The results of the concluding diagnostics of comparison of the readiness for self-development indicators in students of group I and group II

\begin{tabular}{llllllll}
\hline $\begin{array}{l}\text { Self-development } \\
\text { indicators }\end{array}$ & $\begin{array}{l}\text { Rank Sum } \\
\text { group I }\end{array}$ & $\begin{array}{l}\text { Rank } \\
\text { Sum } \\
\text { group II }\end{array}$ & U & Z & p-value & $\begin{array}{l}\text { Z } \\
\text { adjusted }\end{array}$ & $\begin{array}{l}\text { p- } \\
\text { value }\end{array}$ \\
\hline General & 10938 & 9972 & 4821 & 0.9 & 0.37 & 0.9 & 0.37 \\
Conditions & 11317 & 9593 & 4442 & 1.8 & 0.07 & 1.8 & 0.07 \\
Mechanisms & 11291 & 9618.5 & 4467.5 & 1.74 & 0.08 & 1.75 & 0.08 \\
Motivational & 11085 & 9825 & 4674 & 1.25 & 0.21 & 1.25 & 0.21 \\
Gnostic & 11227.5 & 9682.5 & 4531.5 & 1.59 & 0.11 & 1.59 & 0.11 \\
Moral-and-will & 11334 & 9576 & 4425 & 1.84 & 0.07 & 1.84 & 0.07 \\
Self-management & 11285 & 9625 & 4474 & 1.72 & 0.08 & 1.73 & 0.08 \\
Communicative & 10989 & 9921 & 4770 & 1.02 & 0.31 & 1.03 & 0.31 \\
\hline
\end{tabular}

The raise in readiness for self-development indicators in students of group II and their levelling with those of group I attests to efficiency of the developed and implemented by the authors technology of the formation of readiness for selfdevelopment in students from the occupied territories and the delimitation line in the east of Ukraine.

\section{Discussions}

Developing the technology of the formation of readiness for self-development in students in conditions of a displaced HEI, the authors departed from the thought that the presence of a certain level of readiness for self-development enables students to determine their own goals concerning the sense of living, professional activity, personal relations, self-preparation for the future, for any changes, obstacles, choice of means of implementing the set goals and tasks. Therefore, this technology had to be applied throughout the whole organization of the training process at the HEI, which calls for conceptual substantiation.

The theoretic-and-methodological basis of the research is formed by the following complex of scientific approaches:

1) competency (forming in students from the occupied territories and the delimitation line the competencies which facilitate self-development. These are such competencies which are represented by abilities for research, control, the ability for problems solving, taking justified decisions, teamwork, planning and timemanagement, creativity, communicative skills, ability to present information, adapting and acting in a new situation, doing socially responsible and conscious actions, showing initiative and entrepreneurship, etc. They are formed by the block of general humanities subjects, a professional cycle of disciplines through specifying the program results of education in tasks of various disciplines);

2) activity (forms and methods of the technology of the formation of readiness for self-development in students from the occupied territories and the delimitation line which are oriented at involving students in such an activity in the education process that forms this readiness. This is training with tasks on self-development in all 
training subjects, involving students in the activity which forms this readiness or its separate components);

3) synergy (a personality of a student is viewed upon as a complex self-organizing system, on which somebody else's ways of the development cannot be imposed, that is why the work should be aimed at promoting a personality's own tendencies and peculiarities in development through creating conditions, actuation resources of selfdevelopment, which will raise the competitiveness and successful professional activity). Synergic approach enables to discard the variety of elements of which this or other process consists, highlighting the so-called parameters of order that the prevail at the moment of self-organization. Correspondently, such parameters were determined from the aforementioned self-development components, by which the difference was observed between students' of group I and group II and which acted as components of the content of the developed technology. These parameters, in essence, have become the criteria of its efficiency;

4) acmeological approach (its chief technological task is forming and fixing in students' from the occupied territories and the delimitation line in the east of Ukraine self-consciousness the need in self-development that presupposes explaining it and showing perspectives of its formation);

5) axiological approach (realizing by students the value of professional selfdevelopment and teachers' educational work in the training process concerning the formation of this value in students);

6) personality oriented approach (it enables organizing the formation in students of readiness for self-development relying on self-education targeted at strengthening the self-development motivation in specialists-to-be on the basis of the individual development trajectory with taking into account students' choices in the education process);

7) system approach (all components of the technology of the formation of readiness for self-development in students from the occupied territories are interconnected, interrelated, and interdependent, and the technological process of the formation of the corresponding readiness in them is a system of training, education, and education management. A system-forming factor that unites the whole system is the goal - the formation in students of readiness for self-development;

8) reflexive approach (a future specialist's self-development presupposes not only the qualitative performance of some activity, but an ability for self-analysis that makes up the foundation of permanent professional self-development. This presupposes training students in self-reflection and teachers' work in this direction);

9) resource approach (a future specialist's self-development is formed not only from the present-day position, but from the point of perspective. The resources of the HEI and of the community, a student is placed into, have been determined, and there have been established student's resources that facilitate personality's selfdevelopment, along with characteristics and traits that impede self-development);

10) socio-pedagogic approach (positive factors of personality development are amplified and supported, while negative factors are oppressed and removed, limited. In practice, this means involving students in positive activity concerning selfdevelopment and demonstrating to them positive models of life, forming conditions for intolerance at a HEI towards phenomena that encourage addictive and deviant behavior in students; it also means prevention of negative phenomena in the educational environment.

11) culture-related approach ( it empathizes the importance of taking into account the historical, political, educational, and cultural peculiarities formed in the country, the national and the patriotic ideas in the formation of readiness for selfdevelopment);

12) environmental approach (it is about the subject-to-subject interaction in the displaced HEI environment, the influence of the HEI's image, its reputation, operational mode, educational process organization at HEI in such a manner that would promote the formation of readiness for self-development in students;

13) humanistic approach (the main pedagogic value is a person with his unique ability for self-development), respect to a person and insistence to him in the training 
process, as well as student-centeredness). This presupposes the availability of all disciplines' syllabuses and the content of all educational programs on the web site, the availability of didactic choice for students, taking into account their opinion as chief stakeholders of educational programs (provision of questionnaires on the educational programs' quality and considering opinions expressed in them). This also means showing perspectives in the near and distant future.

14) wholesome approach to education, according to which pedagogic technologies relate to training and education, educational management and at the same time enhance the formation of a wholesome personality;

15) the participation theory developed by the UNICEF, according to which the highest democracy level which promotes the formation of the subject status of a person in the course of life, is his own decision making; in this case - students' decision on their education at a displaced HEI made by students themselves;

16) problem-oriented approach in which the main and basic students' needs and problems must be taken into account and solved;

17) the resilience theory which provides for reliance on the strengths of the students and the situation.

The enumerated approaches stipulate observation of the following principles in substantiation of the technology of the formation of readiness for self-development: wholesomeness, systemacy, subject-to-subject interaction in education, cognitive independence and formation of positive motivation for learning, continuity of personal and professional development, individualization and differentiation, partnership interaction, communicative activeness, innovativeness, educative training, stimulating students to self-upbringing and self-education, student-centeredness, education in activity and communication targeted at self-development, values of education and self-education, acme-summits in education as alternative to the consumeristic attitude to a HEI and manifestation of subjectivity, education's orientation at development with taking into account perspective lines of each student, national education, tolerance, the "equal-to-equal" principle, social prevention, relying on students' strengths and solving their problems.

The goal of the technology of the formation of readiness for self-development in students from the occupied territories and the delimitation line under conditions of a displaced HEI is seen by the authors in forming in them such a level of readiness for self-development which ensures their competitiveness in the labor market, ability for permanent professional development, and enables attaining success in professional activity. The result will be a competitive specialist capable of permanent professional development and successful in his professional activity, who is the subject of his life in all its spheres. The principal subjects of implementing the technology of the formation of readiness for self-development are as follows: 1) students from the occupied territories and the delimitation line in the east of Ukraine (at whom the developed pedagogic technology is directed); 2) the heads (deans) of the institutes (faculties), their deputies on training and socio-humanitarian work, lecturers, students from the safety zone, graduates, specialists in various branches, potential employers (those who implement this technology).

The formation of readiness for self-development in students from the occupied territories and the delimitation line under conditions of a displaced HEI consists of the following stages: the $1^{\text {st }}$, preparatory one - the stage of conducting initial diagnostics of the state of readiness for self-development in students who study at a displaced HEI, comparative analysis of the results obtained in groups of students from the occupied territories and the delimitation line in the east of Ukraine and those from the safety zone, followed by development of the pedagogic technology of the formation of readiness in such students with taking into account the diagnostics results, studying its goals and the expected effect, contents, the main types of activities, methods, forms, etc. In essence, at this stage such sub-stages of it are implemented as students' diagnostics and self-diagnostics, projecting of further work on the problem by teachers together with students (prognosticating, goals-formation, technology modelling, planning the algorithms of action); the $2^{\text {nd }}$, the main stage - activities proper on technology implementation with the use of the totality of the selected 
content, forms and methods satisfying the goals, each of which is targeted at solving individual tasks, ensuring in their sum total the attaining of the set goal. In the second stage, it is possible to single out such sub-stages as technology implementation with its organization, management, and current control. They facilitate individualization and differentiation of the developed technology. The $3^{\text {rd }}$, final stage, supposes estimation and results analysis, determining further perspectives of the technology. At this stage, final control, comparing and testing the pedagogic technology are made, the obtained result is compared to the planned one, the conducted work is analyzed, shortcomings are corrected or eliminated, the possibility of its further application is determined. That is why, for this stage, the following algorithm is designated: final diagnostics - estimation and self-evaluation - correction of the outcomes.

The content of education, on which the technology of the formation of readiness for self-development in students in the conditions of a displaced HEI, included all the training disciplines (subjects) at the HEI and extracurricular work: educative (upbringing), scientific, and social. This is fixed in the plans of these kinds of work and reflected in the project tasks approved at the HEI. Therefore, the content is formal and informal students' education on self-development problem. Having determined the stages in the technology of the formation of readiness for self-development in students from the occupied territories, the authors move on to characterizing such its components as forms and methods. The forms and methods applied in implementation of the mentioned technology can be subdivided: 1) by the number of participants individual, group, mass; 2) by the predominant source of information - practical (a conference, a seminar, a training, a practice session, a round table, a master class); 3) visual (an exhibition, a presentation, video materials); 4) language-related (oral: a dispute, an open lecture, a talk, meetings with potential employers and specialists in various branches; work with printed materials: referring to literature and information sources); 5) by the character of cognitive activity (traditional, innovative, active, interactive); 6) by kinds of activity (information, training, creative, communicative). The main methods of implementing the technology were as follows: 1) educational methods: a) consciousness formation (a dispute, an example, persuasion); b) activity organization (prognostication, exercises, examples of people who achieved success in life or lost the sense of living); c) activity stimulation (approval, reinforcement, trust, criticizing, competition, organization of demonstration of a positive and negative perspective); d) self-education (self-analysis, self-evaluation, self-order, self-control, self-correction); 2) methods of training: a) methods to form a positive selfdevelopment motivation: (didactic games, demonstration of perspective, situations of success, etc.) and stimulating students to self-development (scientific works competitions, Miss and Mr. University, thematic weeks in various subjects, competition in computer literacy, Ukrainian language, etc., letters to parents about their children's success); b) methods of organizing cognitive activity related to selfdevelopment (a dialogue, pedagogic circles (groups), exercises, research work, individual work); c) methods of self-development control (applying knowledge in changed situations, transferring of the learnt principles and actions on solving more complicated tasks, self-control and self-evaluation methods); 3) managerial (common setting of goals, making managerial decisions, joint planning, social partnership, coordination, etc.); 4) empirical methods of science-and-pedagogic research (interviewing, observation, analyzing students' activity results, their activeness, generalizing independent characteristics, etc.).

The conditions of a successful implementation of the technology lie in the formation of decent living conditions (housing, material, economic, legal, sociomedical, socio-psychological, socio-pedagogic, organization, etc.) for students' selfdevelopment and satisfaction of their basic needs with simultaneous formation of students' readiness for self-development. To this effect, the HEI and the state organize for internally displaced persons (IDPs) the following events and provide the following assistance: a monthly house-renting assistance for IDPs, granting a place at a hostel, assistance in documents registration, in students' socialization at HEI, in their getting a social scholarship (work of deans' deputies for socio-humanitarian work), legal consultation for students based on the equal-to-equal method for solving legal issues, 
work of a medical room at a HEI for students and teachers, students' social service at a HEI, operation of the Center on international and training-and-education work, the development Center. Partnership relations have been established with social services and region councils of local districts based on agreements on cooperation which broadens the range of social and psychological services available for students, etc.

It is determined that the main parameters of students' readiness for selfdevelopment are the need in self-development, conditions, mechanisms, selfmanagement, gnostic, organization, cognitive, motivational, moral-and will, and communicative components. By these parameters, it was found that the initial state of readiness for self-development in students from the occupied territories and the delimitation line in the east of Ukraine together with the students from the safety zone was characterized by the same indicators of the need in self-development, its cognitive and organization components, but at the same time, a much lower readiness level by such indicators as self-management, gnostic, motivation, moral-and-will, communicative components, conditions, mechanisms, self-development general level was observed. On the grounds of the obtained results, the technology of the formation of readiness for self-development in students from the occupied territories and the delimitation line in the east of Ukraine was theoretically substantiated.

The scientific novelty of the research is the substantiation of this technology. Its theoretical foundation is a complex of scientific approaches and principles that were selected on the basis of their application. The goal of the technology is the formation of readiness for self-development in students from the occupied territories and the delimitation line, and its main stages are the preparatory stage (initial diagnostics prognostication - goals setting - modelling - planning), the main stage (organization - management - current control), and the final stage (result - final diagnostics estimation and self-evaluation - correction). The efficiency of the authors' technology is proved by students' from the occupied territories attaining the readiness for selfdevelopment level which corresponds to that of the students from the safety zone that confirms the expediency of applying this technology in activities of displaced HEIs. The perspective of further research is following the careers of the graduate students from the occupied territories in the east of Ukraine as one of the directions of work of HEIs' Career Development Centres in conditions of creating the cooperation platform on the issues of higher education applicants' employment, involvement of potential employers in the process of informal education at the university, improving the quality of education oriented at preparing a competitive human capital.

\section{References}

1. Akhmetov A. M. (2004). Motivation Stimulating of Physical Self-Perfection in a Student Teacher-to-Be. Cand. Sci. Thesis in Pedagogics, Naberezhniye Chelny. (in Russian).

2. Alpatova V. V. (2012). Psychological Guide for Self-Development of Professional Skills of a Pedagogue. For a School Psychologist. Everything Needed for Work. 11, 2-5. (in Ukrainian).

3. Babak K. V. (2011). Psychologic Support of Pedagogic College Students' Pedagogic Development. Cand. Sci. Thesis in Psihology, Kyiv. (in Ukrainian).

4. Blinova V. L. and Blinova Yu. L. (2009). Psychologic Foundations of Self-Cognizance and Self-Development, Kazan: TGGPU. (in Russian).

5. Chaltseva O. M. (2019). Possibilities and Problems of Getting High Education by Children from Occupied Territories. Political Life 2, 27-32. (in Ukrainian).

6. Chorna N. B. (2016). Readiness for Professional Self-development Formation in Future Teachers of Artistic Specialties. Cand, Sci. Thesis in Pedagogics, Vinnytsya. (in Ukrainian).

7. Day C., Kington A., Stobart G. and Sammons P. (2006). The Personal and Professional Selves of Teachers: Stable and Unstable Identities. British Educational Research Journal 32 (4). $10.1080 / 01411920600775316$.

8. Frytsiuk V. (2016). Organizational and Pedagogical Conditions of the Formation of Readiness of a Future Pedagogue for Continuous Prefessional Self-Development. Continuous Professional Education: Theory and Paratice 3-4 (48-49). http://npo.kubg.edu.ua/article/view/182459. (in Ukrainian). 
9. Frytsiuk V. A., Groshovenko O. P. (2018). Professional Self-Development of Future Pedagogues: A Competence-Based Approach. The Bulletin of Alfred Nobel University 1 (15), 208-213. (in Ukrainian).

10. Gheith E. and Aljaberi N. (2018). Reflective Teaching Practices in Teachers and Their Attitudes toward Professional Self-Development. International Journal of Progressive Education 14 (3). 10.29329/ijpe.2018.146.11.

11. Hamman D., Gosselin K., Romano J. and Bunuan R. (2010). Using possible-selves theory to understand the identity development of new teachers. Teaching and Teacher Education 26. 10.1016/j.tate.2010.03.005.

12. Hong J., Greene B. and Lowery J. (2017). Multiple dimensions of teacher identity development from pre-service to early years of teaching: a longitudinal study. Journal of Education for Teaching: International research and pedagogy 43 (1). 10.1080/02607476.2017.1251111.

13. Ignatyuk O. A. (2009). Theoretical and Methodological Bases of Trainign a Future Engineer for Self-Perfection in Conditions of a Technical University. Thesis. Kharkiv: NTU "KhPI". (in Ukrainian).

14. Kasyanova A. V. and Kolosov A. M. (2018). Foundations of the Formation of Adaptive Mechanisms of Renovation of Functioning of Temporarily Displaced Educational Institutions. The Bulletin of Luhansk Taras Shevchenko National University 1 (315), 105 - 117. (in Ukrainian).

15. Kelchtermans G. (2009). Who I Am in How I Teach Is the Message: Self-Understanding, Vulnerability and Reflection. Teachers and Teaching : theory and practice. 15 (2). $10.1080 / 13540600902875332$.

16. Kravchenko V. N. (2016). Ways of Formation of Readiness of Future Teracgers of High Schools for Professional Self-Perfection in the Process of Extra-Curricular Activities. ScienceRise: Pedagogical Education 12 (8), 14-17. (in Ukrainian).

17. Kucheryavenko I. A. (2011). Problem of Psychological Readiness for Professional Activity Young Scientist 12 (2), 60-62. (in Ukrainian).

18. Kurylo V. S., Savchenko S. V., Karaman O. L. (2019). Displaced Universities As a New Type of Institutions of Higher Education. Education and Pedagogical Sciences 3 (172), 50-58. (in Ukrainian).

19. Kurylo V. S., Savchenko S. V., Karaman O. L. and Menyailenko O. S. (2020). Soft Skills for a Displaced Higher Educational Establishment: realization of Ideas for a Divided University. Collection of Regional Science-and-Practical Conference Articles Hard / Soft Skills of a New Generation Specialist (Lysychansk: FOP Yegorova O. Ye.), pp. 117-124. (in Ukrainian).

20. Kurylo V., Savchenko S. (2019). Temporarily Displaced Higher Educational Establishments As a New Social Phenomenon. International Science-and-Practical Conference "Socioligy and Social Work under Conditions of National and Regional Challenges ed I V Kozubovska and F F Shandora (Uzhgorod: "RIK-U Ltd"), pp. 54-56. (in Ukrainian).

21. Kuzikova S. B. (2015). Analysis of Self-Development As a System-Defined Phenomenon of Self-Modification of an Individual. The Bulletin of KhNPU after G.S. Skovoroda. Psychology 51, 100-109. (in Ukrainian).

22. Kuzikova S. B. (2020). Psychological Foundatrions of the Formation of the Subject of SelfDevelopment in the Adolescent Age. Monograph. Sumy: SumDPU. (in Ukrainian).

23. Lankveld T. van, Schoonenboom J., Volman M., Croiset G. and Beishuizen J. (2017). Developing a teacher identity in the university context: a systematic review of the literature. Higher Education Research \& Development 36 (2). 10.1080/07294360.2016.1208154.

24. Liulyov O. V., Pylomenko T. V., Yaskevych A. O. (2018). Index of Global Competitiveness: Experience of EU for Ukraine. International Relations 1 (15), 67-70. (in Ukrainian).

25. Martyniuk I. A. (2019). Readiness for Self-Educational Activity in the Structure of Student's Personality. Psychological Journal 5 (6). 10.31108/1.2019.5.6.10. (in Ukrainian).

26. Minyurova S. A. (2013). Psychology of Self-Cognizance and Self-Development, Yekaterinburg: The Ural State Pedagogic University. (in Russian).

27. Myronchuk N. M. (2013). Prefessional and Personal Development of a Future Pedagogue: Essential Characteristics and Ways of Formation. New Teaching Technologies 76, 209-214. (in Ukrainian).

28. Nevgi A. and Löfström E. (2015). The Development of Academics' Teacher Identity: Enhancing Reflection and Task Perception Through a University Teacher Development Programme. Studies in Educational Evaluation 46, 53-60. 10.1016/j.stueduc.2015.01.003.

29. Pithouse K., Mitchell C. and Weber S. (2009). Self-Study in Teaching and Teacher Development: a Call to Action. Educational Action Research 17 (1), 43-62. 
30. Polyakov A. O. (2008). Pedagogic Conditions of Professional Growth Motivation in Pedagogy University Students in the Process of Permanent Education. Cand. Sci. Thesis in Pedagogics, Kharkiv. (in Ukrainian).

31. Rodgers C. R. and Scott K. H. (2008). The Development of the Personal Self and Professional Identity in Learning to Teach. Handbook of Research on Teacher Education: Enduring Questions in Changing Contexts. Ed. M. Cochran-Smith, S. Feiman-Nemser, D. J. McIntyre and K. E. Demers, (New York: Routledge, Taylor \& Francis Group / Association of Teacher Educators) pp. 732-755.

32. Rybalko L. S., Chernovol-Tkachenko P. I., Kutsenko T. V. (2017). Acmeological Principles of Teachers' Prodessional Self-Actualization in the Methodology Work System of General Education Training Institutions. Kharkiv: Osnova. (in Ukrainian).

33. Sarkisova U. (2015). Formation of Readiness of Future Teachers of Economics for Professional and Pedagogical Self-Development on the Basis of Group Interaction. Topical Problems of Sociology, Psychology, and Pedagogy 1 (26), 142-148. (in Ukrainian).

34. Smolyuk A. I. (2017) Emperical Analysis of Individual Indicators of Formation of Professional Self-Development of Future Teachers of Primary School. Pedagogic Sciences 68, 85-92. (in Ukrainian).

35. Smolyuk A. I. (2017). Professional Self-Development of Future Primary School Teachers in the Education Environment of a Pedagogical College. Cand. Sci. Thesis in Pedagogics. Kyiv. (in Ukrainian).

36. The Law of Ukraine "On Education" (2017). No. 2145-VIII dated 05 September 2017 https://zakon.rada.gov.ua/laws/show/214519?find=1\&text=\%D1\%81\%D0\%B0\%D0\%BC\%D0\%BE\#w1_1.

37. The Law of Ukraine "On Higher Education" (2014). No. 1556-VII dated 01 July 2014 https://zakon.rada.gov.ua/laws/show/1556-18\#Text.

38. Trubavina I. M. (2015). Problems of Internally Displaced Persons in Ukraine As a Foundation of Social and Pedagogical Work with Them. Pedagogic Sciences: Theory, History, Innovation Technologies 8 (52), 434-446. (in Ukrainian).

39. Trubavina I. M. (2018). Formation of Tolerance and Culture of Peace in Pupils of Institutions of General Secondary Education: Social and Pedagogical Aspect. The Bulletin of Luhansk Taras Shevchenko National University 3 (137), 115-124. (in Ukrainian).

40. Trubavina I. M. et al. (2017). Methodological Recommendations as to Organization of Extracurricular Activities at Schools in Order to Instill Dignity, Peace, and Social Consensus. Kharkiv: Planeta-Print. (in Ukrainian).

41. Trubavina I., Vasylieva S. and Martyniuk A. (2020). Analysis of the state of formation of future teacher's communicative competence as a condition of providing the quality of general secondary education. SHS Web of Conferences : ICHTML $\mathbf{7 5} 02006$ 10.1051/shsconf/20207502006.

42. Trubavina I. M., Kaplun S. O. (2019). Subjectness of Students as a Pedagogical Condition of Formation of Their Cognitive Independence in Studying. Fundamental And Applied Researches: Contemporary Scientifical and practical Solutions and Approaches. Interdisciplinary Prospects vol 5, ed A Dushniy, M Makhmudov and M Strenacikova. (Baku Banska Bystrica - Uzhhorod - Kherson: Posvit) pp. 288-292. (in Ukrainian).

43. Tsyna A. (2012). Pedagogical Technologies of Increase of Level of Motivation of Social Security of an Individual in the Professional Trainign of a Future Teacher. The Youth ad the Market 9 (92), 35-41 (in Ukrainian).

44. Urzua A. and Vasquez C. (2008). Reflection and Professional Identity in Teachers' FutureOriented Discourse. Teaching and Teacher Education 24, 1935-1946. 10.1016/j.tate.2008.04.008.

45. Yazan B. (2018). TESL Teacher Educators' Professional Self-Development, Identity, and Agency. TESL Canada Journal 35 (2). 10.18806/tesl.v35i2.1294.

46. Zelenov Ye. (2015). Spetirual Self-Development and Self-Organization of an Individual As A Constituent Part of the Global Upbringing of Students' Youth. Personality Spirituality: Methodology, Theory and Practice 3 (66), 85-94. (in Ukrainian).

47. Zubchyk O. A. (2014). Qualitative High Education: Formation of Human Capital and Increase of Competitiveness of the State. Public management 1 (1), 25-28. (in Ukrainian). 